\title{
Local tumor control and toxicity in HIV-associated anal carcinoma treated with radiotherapy in the era of antiretroviral therapy Christoph Oehler-Jänne ${ }^{1}$, Burkhardt Seifert ${ }^{2}$, Urs M Lütolf ${ }^{1}$ and I Frank Ciernik*1
}

\author{
Address: ${ }^{1}$ Radiation Oncology, Zurich University Hospital, Switzerland and ${ }^{2}$ Department for Social- and Preventive Medicine, Biostatistics, \\ University of Zurich, Zurich, Switzerland \\ Email: Christoph Oehler-Jänne - christoph.oehler@usz.ch; Burkhardt Seifert - seifert@ifspm.unizh.ch; Urs M Lütolf - urs.luetolf@usz.ch; I \\ Frank Ciernik* - ciernik@iosi.ch \\ * Corresponding author
}

Published: 18 August 2006

Radiation Oncology 2006, I:29 doi:10.1186/1748-7/7X-1-29

This article is available from: http://www.ro-journal.com/content/I/I/29

(C) 2006 Oehler-Jänne et al; licensee BioMed Central Ltd.

This is an Open Access article distributed under the terms of the Creative Commons Attribution License (http://creativecommons.org/licenses/by/2.0), which permits unrestricted use, distribution, and reproduction in any medium, provided the original work is properly cited.
Received: II May 2006

Accepted: 18 August 2006

\begin{abstract}
Purpose: To investigate the outcome of HIV-seropositive patients under highly active antiretroviral treatment (HAART) with anal cancer treated with radiotherapy (RT) alone or in combination with standard chemotherapy (CT).
\end{abstract}

Patients and methods: Clinical outcome of 8 I HIV-seronegative patients (1988 - 2003) and 10 consecutive HIV-seropositive patients under HAART (I997 - 2003) that were treated with 3-D conformal RT of 59.4 Gy and standard 5-fluorouracil and mitomycin-C were retrospectively analysed. 10 TNM-stage and age matched HIV-seronegative patients (1992-2003) were compared with the 10 HIV-seropositive patients. Pattern of care, local disease control (LC), overall survival (OS), cancer-specific survival (CSS), and toxicity were assessed.

Results: RT with or without CT resulted in complete response in $100 \%$ of HIV-seropositive patients. LC was impaired compared to matched HIV-seronegative patients after a median followup of 44 months $(p=0.03)$. OS at 5 years was $70 \%$ in HIV-seropositive patients receiving HAART and $69 \%$ in the matched controls. Colostomy-free survival was $70 \%(\mathrm{HIV}+)$ and $100 \%$ (matched HIV-) and 78 \% (all HIV-). No HIV-seropositive patient received an interstitial brachytherapy boost compared to $42 \%$ of all HIV-seronegative patients and adherence to chemotherapy seemed to be difficult in HIV-seropositive patients. Acute hematological toxicity reaching $50 \%$ was high in HIVseropositive patients receiving MMC compared with $0 \%$ in matched HIV-seronegative patients ( $p$ $=0.05$ ) or $12 \%$ in all HIV-seronegative patients. The rate of long-term side effects was low in HIVseropositive patients.

Conclusion: Despite high response rates to organ preserving treatment with RT with or without CT, local tumor failure seems to be high in HIV-positive patients receiving HAART. HIVseropositive patients are subject to treatment bias, being less likely treated with interstitial brachytherapy boost probably due to HIV-infection, and they are at risk to receive less chemotherapy. 


\section{Background}

The incidence of cancer of the anal canal is rising due to the increasing prevalence of HIV-infection and HPV-infection [1-4]. Standard therapy for invasive anal cancer is radiotherapy (RT) or chemo-radiation resulting in local tumor control (LC) rates and disease-free survival (DFS) in HIV-seronegative patients approaching $72 \%$ and $73 \%$, respectively [5-7]. Few data exist on treatment outcome in HIV-seropositive individuals. Retrospective survival analyses of cohort patients in the pre-HAART era indicate that HIV-infection is associated with poorer outcome after combined chemo-radiation [7-10]. Though, some investigators reported lower doses of RT and chemotherapy being applied in patients with HIV-infection $[3,11]$. Sideeffects tended to be more frequent and more intense in HIV-seropositive patients without HAART than in HIVseronegative patients in some reports [12-14] whereas in others acute toxicity was moderate [15]. The increased likelihood of therapy-related toxicity correlated with low CD4 count in HIV-seropositive patients in the pre-HAART era in one report [16].

The introduction of HAART resulted in an increase of CD4 counts in responders and prolongation of survival. The influence of HAART on concomitant cancer treatmentrelated toxicity and treatment outcome of anal cancer remains controversial. Analysing very small patient cohorts, some authors showed no changes of the overall survival (OS) rates of anal cancer since the introduction of HAART [1] while others reported favorable treatment and toxicity outcome compared with results of the non-HIV population $[17,18]$.

The aim of this study was to investigate clinical characteristics of HIV-seropositive and HIV-seronegative patients and whether the outcome in respect of treatment toxicity and survival after standard curative 3-D conformal RT with or without chemotherapy (CT) of invasive cancer of the anal canal is comparable between HIV-seropositive patients receiving HAART and stage and age matched HIVseronegative patients.

\section{Patients and methods Patients}

Ninety-one patients presenting with histologically proven invasive carcinoma of the anal canal between 1988 and 2003 at the Department of Radiation Oncology, Zurich, were treated with curative 3-D conformal RT alone or combined with CT. First, clinical characteristics, pattern of care and outcome of $81 \mathrm{HIV}$-seronegative patients were retrospectively analysed. Then, 10 consecutive HIV-seropositive patients receiving HAART (1997 and 2003) were retrospectively compared to $10 \mathrm{HIV}$-seronegative patients (1992 - 2003) matching for TNM-stage and age. Selection of matched HIV-negative patients was as follows: of 81
HIV-seronegative patients with invasive carcinoma of the anal canal, 42 patients matched for TNM-stage and of these 42 patients 10 patients corresponded for age and grading. After obtaining informed consent and internal institutional review approval, clinical outcome was analyzed by reviewing medical records and interviews of patients.

Pre-treatment staging was performed in all patients and included digital examination, endoluminal ultrasound, chest $\mathrm{x}$-rays and either an abdominal ultrasound or CT scanning. Patients were staged according to the system adopted by the American Joint Committee on Cancer [19] and the Union International Contre le Cancer (UICC) before the primary treatment [19]. Post-treatment evaluation included a clinical examination including digital palpation at each visit and regular anal ultrasounds. Anoscopy and post-treatment biopsies were only performed when a suspicious lesion was identified.

\section{Treatment}

No patient in the HIV-seropositive had primary radical surgery with colostomy compared with 5 HIV-seronegative patients $(6 \%)$. All patients except one HIV-negative patient that died during treatment completed curative 3-D conformal RT. Standard RT was administered over a fiveweek period to a dose of 45 Gy in 1.8 Gy per fraction followed either directly by an external beam radiotherapy (EBRT) boost or an interstitial high-dose rate ( ${ }^{192}$ Ir-HDR) boost after an interval of $2-3$ weeks to deliver a total dose of 59.4 Gy. The fractionated HDR brachytherapy boost (14 Gy/7 fractions, thrice daily) was applied to patients with T1 - T3 tumors appropriate for interstitial treatment after EBRT of 45 Gy.

Chemotherapy consisted of fluorouracil (5-FU) and mitomycin-C (MMC). 5-FU was applied as a continuous infusion during the first five days of radiotherapy at a dose of $750 \mathrm{mg} / \mathrm{m}^{2}$ or over four days at $1000 \mathrm{mg} / \mathrm{m}^{2}$. The cycle was repeated during week five of RT. MMC was given as an i.v. bolus on day one of radiotherapy $\left(15 \mathrm{mg} / \mathrm{m}^{2}\right)$ or twice during week 1 and $5\left(10 \mathrm{mg} / \mathrm{m}^{2}\right)$. When contraindicated, MMC was replaced by cisplatin given i.v., during 1 hour infusion, in week 1 and 5. Criteria for "non-adherence to chemotherapy" included omittance of chemotherapy or dose-reduction because of side effects.

\section{Toxicity}

The common terminology criteria for adverse events v3.0 was used for assessing acute and late treatment toxicity [20]. Follow-up records addressing long-term toxicity were available for $95 \%$ of the patients. Sphincter function was assessed by digital palpation. 


\section{Statistics}

Mean values are indicated with standard deviation. Differences between groups on continuous variables were tested using the Mann- Whitney test. SPSS version 12 was used with exact $p$-values. Fisher's exact test was used to test for differences between groups on categorical variables. Survival was calculated from the beginning of RT to the day of death or the date of last follow-up and time-to- recurrence from beginning of RT to the day of recurrence or date of last follow-up. Survival curves for the two groups were plotted according to the Kaplan-Meier method. Differences in survival across the groups were tested using the Log rank (Mantel-Cox) test.

\section{Results}

\section{Results of HIV-seronegative patients}

Mean age of the $81 \mathrm{HIV}$-seronegative patients was $61.6+$ / - 12.7 years and $75 \%$ of the patients were female (Table $1)$. Sixty-one patients $(74 \%)$ had a very good performance status (WHO $0^{\circ}$ ). Nine patients $(11 \%)$ had grad 1 and 3 patients $(4 \%)$ grade 2 WHO performance status and for 7 patients it was not known. At time of diagnosis, tumor stage distribution for T1/T2/T3/T4 was $15 \%, 43 \%$, $31 \%$ and $11 \%$. The majority of patients presented with

Table I: Clinical characteristics, pattern of care and outcome of HIV-seronegative patients $(n=8 I)$. MMC = mitomycin-C, $R T=$ radiotherapy, OS = overall survival, CSS $=$ cancer-specific survival, $\mathbf{m}=$ months.

\begin{tabular}{|c|c|}
\hline Variable & HIV-seronegative patients \\
\hline gender & $m: f=20: 6 \mathrm{I}(24.7 \%)$ \\
\hline age & $61.6+/-12.7 y$ \\
\hline WHO performance status $I^{\circ}$ & $14.8 \%$ \\
\hline TI/T2/T3/T4 & | $4.8 \% / 43.2 \% / 30.9 \% /$ I I.I \% \\
\hline N0/NI/N2/N3 & $60.5 \% / 17.3 \% / 11.1 \% / 8.6 \%$ \\
\hline G I/G 2/G 3 & $8.6 \% / 53.1 \% / 27.2 \%$ \\
\hline sphincter invasion & $25(30.9 \%)$ \\
\hline histology (basaloid) & $25(30.9 \%)$ \\
\hline radical surgery & $5(6 \%)$ \\
\hline chemotherapy & $58(71.6 \%)$ \\
\hline MMC & $52(64.2 \%)$ \\
\hline RT-dose & $57.2+/-5 \mathrm{~Gy}$ \\
\hline RT-duration & $53.6+/-17.3 d$ \\
\hline brachytherapy & $34(41.9 \%)$ \\
\hline follow-up (median/mean) & $45 \mathrm{~m} / 5 \mathrm{l}+/-34 \mathrm{~m}$ \\
\hline OS at 10 years & $48 \%$ \\
\hline CSS at 10 years & $75.1 \%$ \\
\hline acute side effects $\left(3^{\circ}\right)$ & $25(30.9 \%)$ \\
\hline skin & $14(17.3 \%)$ \\
\hline diarrhea & $5(6.2 \%)$ \\
\hline hematological (\% of MMC patients) & $6(11.5 \%)$ \\
\hline infection & $3(3.7 \%)$ \\
\hline other & I (I.2\%) \\
\hline chronic side effects $(n=54)$ & $13(24 \%)$ \\
\hline ulcera & I (I.9\%) \\
\hline $\begin{array}{l}\text { proctitis } \\
\text { prits }\end{array}$ & 6 (II.1\%) \\
\hline sphincter pressure impairment & $8(14.8 \%)$ \\
\hline
\end{tabular}

nodal negative disease (61\%) and low grad tumors, i.e. G1 and G2 (62\%). Radical surgery with up-front colostomy was performed in $6 \%$ of the patients. All of them received postoperative $\mathrm{RT}$ or chemo-radiation. RT-dose was $57.2+/-5$ Gy and RT-duration was 53.6 +/- 17 days. Interstitial 192 Ir-HDR brachytherapy boost was appropriate in $42 \%$. CT was applied to $72 \%$ and included MMC in $64 \%$ of all patients. After a median follow-up of 45 months OS at 10 years was $48 \%$ and CSS was $75 \%$. Local failure rate at 10 years was $13 \%$. Eleven patients received salvage surgery resulting in a 10 -year colostomy-free rate of $84 \%$ (78\% if the 5 patients with primary radical surgery are included). Two of them had not achieved complete response to chemo-radiation. Severe acute side effects were relatively rare with $31 \%$. The most frequent severe side effects were dermatitis $(17 \%)$, diarrhea $(6 \%)$ or thrombopenia (12\%). Two patients died during or immediately after treatment due to cerebral bleeding under thrombopenia or cardiac failure. Chronic side effects could be evaluated in 54 patients (67\%). Thirteen patients $(24 \%)$ experienced either ulcera (2\%), chronic proctitis $(11 \%)$ or sphincter pressure impairment $(15 \%)$.

\section{Results of HIV-seropositive patients receiving HAART and matched-pair analysis}

\section{Patient's characteristics}

Mean age of HIV-seropositive patients was low with 44.5 +/- 10 years and most of them were male gender (90\%) (Table 3). All $10 \mathrm{HIV}$-seropositive patients were in good health. In patients with HIV-infection, median and mean CD4 counts were $266 / \mu \mathrm{l}$ and $303 / \mu \mathrm{l}(+/-241 / \mu \mathrm{l})$, respectively (Table 2$)$. HIV-seropositive patients presented with early stage ( $80 \% \mathrm{~T} 1 / 2)$, nodal negative (90\%) and well differentiated ( $80 \% \mathrm{G} 1 / 2)$ tumors as shown in Table 3.

\section{Pattern of treatment}

No HIV-seropositive patient received radical surgery with up-front colostomy. Also in the matched HIV-seronegative cohort no patient underwent primary surgery. Total RT dose did not differ between HIV-seropositive and matched HIV-seronegative patients (57 - $58 \mathrm{~Gy}$ ) whereas the duration of RT was longer in the matched HIV-seronegative cohort compared with the matched HIV-negative cohort $(47.4+/-6$ d vs. $59.8+/-10 \mathrm{~d} ; p=0.007)$. This was due to the interval between the EBRT and the brachytherapy boost used in HIV-seronegative patients. A significant difference was observed in the application of HDR-brachytherapy. No HIV-seropositive patient received HDRbrachytherapy boost compared with $60 \%$ of the matched HIV-seronegative patients $(p=0.005)$. Adherence to chemotherapy seemed to be more difficult in HIV-seropositive patients with HAART than in the stage- and agematched HIV-seronegative patients (30\% vs. $80 \%$, respectively; $p=0.08)$. Lack of adherence was either due to non-compliance, co-morbidity or concomitant medica- 
Table 2: Clinical characteristics of HIV-seropositive patients with access to HAART $(n=10)$. TNM: TNM classification of malignant tumors, HAART: Highly active anti-retroviral treatment. * indicates: HAART was started with or immediately before RT. CDC: HIV disease stage (Centers for Disease Control). RT: Radiotherapy. HDR: High-dose-rate brachytherapy. CT: Chemotherapy. 5-FU: Fluorouracil. MMC: Mitomycin-C. f/u: Follow-up. APR: Abdomino-perineal resection. NED: No evidence of disease. MD: Moist desquamation. TC-penia: Thrombocytopenia. I = stavudin, 2 = didanosin, $3=\operatorname{lamivudin}, 4=$ zidovudin, $5=$ efavirenz, $6=$ abacavir, $7=$ ritonavir, 8 = nelfinavir, 9 = amprenavir.

\begin{tabular}{|c|c|c|c|c|c|c|c|c|c|c|}
\hline TNM & CDC & CD4 & HAART & RT (Gy) & $\begin{array}{c}\mathbf{R T} \\
\text { duration } \\
\text { (days) }\end{array}$ & $\begin{array}{l}\text { CT (mg) 5- } \\
\text { FU/MMC }\end{array}$ & $\begin{array}{l}\text { acute } \\
\text { toxicity }\end{array}$ & $\begin{array}{l}\text { chronic side } \\
\text { effects }\end{array}$ & recurrence & $f / u$ \\
\hline TINOMO & $\mathrm{C} 3$ & 80 & $\mathrm{I}, 2,7$ & 54 & 45 & 16100 & & $\begin{array}{c}\text { incontinence } \\
1^{\circ}\end{array}$ & local & $\begin{array}{l}\text { APR, } \\
\text { recurrence }\end{array}$ \\
\hline T3NOMO & $\mathrm{C} 3$ & 847 & I, 3 & 59.4 & 45 & $13600 / 34$ & MD & & none & NED \\
\hline TINOMO & $\mathrm{C} 3$ & 64 & $2,3,6,9$ & 59.4 & 48 & $15400 / 15$ & MD, Tc-penia & skin III' & none & NED \\
\hline T3NOMO & $\mathrm{A} 3$ & 88 & $3,4,5$ & 59.4 & 47 & $14400 / 30$ & & $\begin{array}{c}\text { incontinence } \\
1^{\circ}\end{array}$ & none & NED \\
\hline T2NOMO & $\mathrm{Al}$ & 591 & $\mathrm{I}, 2,7$ & 54 & 60 & $11250 / 40$ & & & loco-regional & $\begin{array}{l}\text { palliation, } \\
\text { failed }\end{array}$ \\
\hline T2NOMO & B3 & 354 & I, $2,8 *$ & 59.4 & 37 & none & MD & & none & NED \\
\hline T2N2MO & C3 & 105 & $3,4,8 *$ & 59.4 & 47 & none & & & none & NED \\
\hline T2NOMO & $\mathrm{C} 3$ & 262 & I, 3, 8 & 59.4 & 56 & $6800 / 20$ & Tc-penia & & inguinal & failed \\
\hline T2NOMO & $\mathrm{C} 3$ & 190 & $3,4,6$ & 55.8 & 43 & none & & & local & APR, NED \\
\hline T2NOMO & $\mathrm{A} 2$ & 370 & $3,4,5$ & 55.5 & 46 & $15520 / 19$ & Tc-penia & & none & NED \\
\hline
\end{tabular}

tion, low CD4 counts, or severe thrombocytopenia before or during treatment.

\section{Response and survival}

Median follow-up was 44 months in the matched groups (HIV+: 8 - 76 months; HIV-: 19 - 116 months). Treatment with RT alone or combined with CT achieved complete remission in $100 \%$ in HIV-seronegative as well as matched HIV-seropositive patients. Three HIV-seropositive patients with HAART suffered from local failure compared with no patient in the age-matched HIV- seronegative cohort, resulting in a statistically worse timeto-local recurrence ( $p=0.03$, Figure 3$)$. Fifty-seven months after treatment, one HIV-seropositive patient suffered from a local relapse while no HIV-seronegative patient experienced local failure after 4 years. Colostomyfree survival was below $70 \%(\mathrm{HIV}+)$ and $100 \%$ (matched HIV-). A non-significant trend towards impaired time-torecurrence for HIV-seropositive patients was observed (4 recurrences in HIV-positive patients versus 1 recurrence in HIV-negative patients; $p=0.1$. In HIV-seropositive patients, local recurrences were histologically confirmed

Table 3: Patient's characteristics of matched HIV-seropositive patients and HIV-seronegative patients matched for TNM-stage and age ( $n=10$ vs. 10).

\begin{tabular}{|c|c|c|c|}
\hline \multirow[t]{2}{*}{ Variable } & \multicolumn{2}{|c|}{ Study group } & \multirow[t]{2}{*}{ Fisher's exact test } \\
\hline & HAART-HIV + & HIV - & \\
\hline gender & $m: f=9: 1$ (90\%) & $m: f=1: 9(10 \%)$ & 0.001 \\
\hline age (mean) & $44.5+/-10 y$ & $45.2+/-7 y$ & NS \\
\hline WHO-perform. Status $I^{\circ}$ & $2(20 \%)$ & 0 & NS \\
\hline TI & 2 & 2 & NS \\
\hline $\mathrm{T} 2$ & 6 & 6 & NS \\
\hline T3 & 2 & 2 & NS \\
\hline No & 9 & 9 & NS \\
\hline N2 & 1 & 1 & NS \\
\hline GI & 2 & & NS \\
\hline $\mathrm{G} 2$ & 6 & 8 & NS \\
\hline G3 & & 2 & NS \\
\hline Sphincter invasion & $2(22 \%)$ & $3(30 \%)$ & NS \\
\hline Histology (basaloid) & $2(20 \%)$ & $4(40 \%)$ & NS \\
\hline Mitomycin C & $6(60 \%)$ & $8(80 \%)$ & NS \\
\hline Brachytherapy & $0(0 \%)$ & $6(60 \%)$ & 0.005 \\
\hline RT-dose (mean) & $57.7+/-2.4 \mathrm{~Gy}$ & $58.5+/-3 \mathrm{~Gy}$ & NS \\
\hline
\end{tabular}




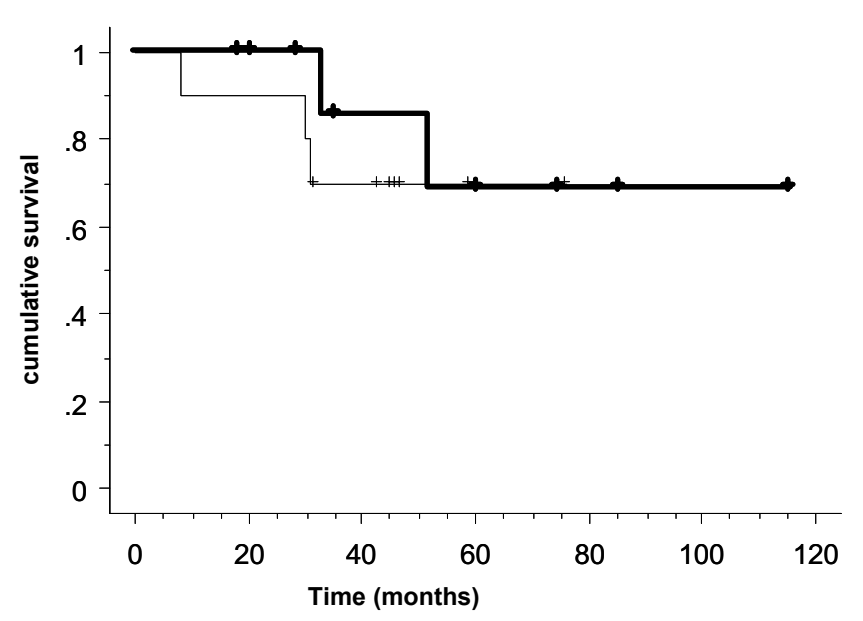

Figure I

Overall survival of HIV-seropositive patients with access to HAART $(n=10)$ (thin line) and T-/N-stage, age-matched HIV-seronegative patients $(n=10)$ (thick line) with anal cancer $(p=N S)$.

in two cases. The two remaining patients suffered from locally extensive tumor disease $(\mathrm{N}=1)$ or additional liver metastasis $(\mathrm{N}=1)$. However, no significant difference in overall and cancer-specific survival was observed (Figure 1 and 2). The 1-year OS in the matched HIV-seropositive and -seronegative cohort was $90 \%$ and $100 \%$, and the 5year OS was $70 \%$ and $69 \%$, respectively. The cause of death in young non-HIV individuals was predominantly secondary cancer. Two $\mathrm{HIV}$-infected patients receiving

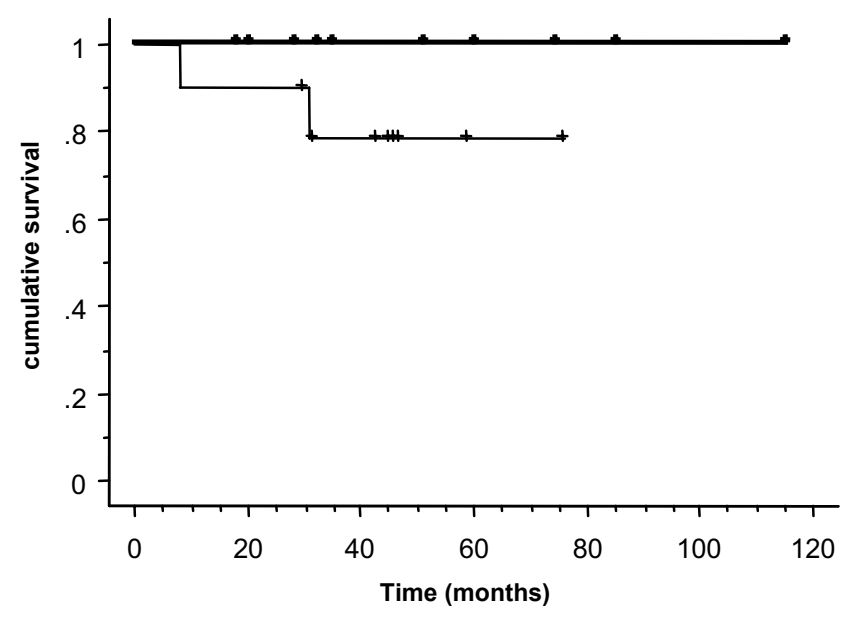

\section{Figure 2}

Cancer-specific survival of HIV-seropositive patients with access to HAART $(n=10)$ (thin line) and T-/N-stage, agematched HIV-seronegative patients $(n=10)$ (thick line) with anal cancer $(p=N S)$.

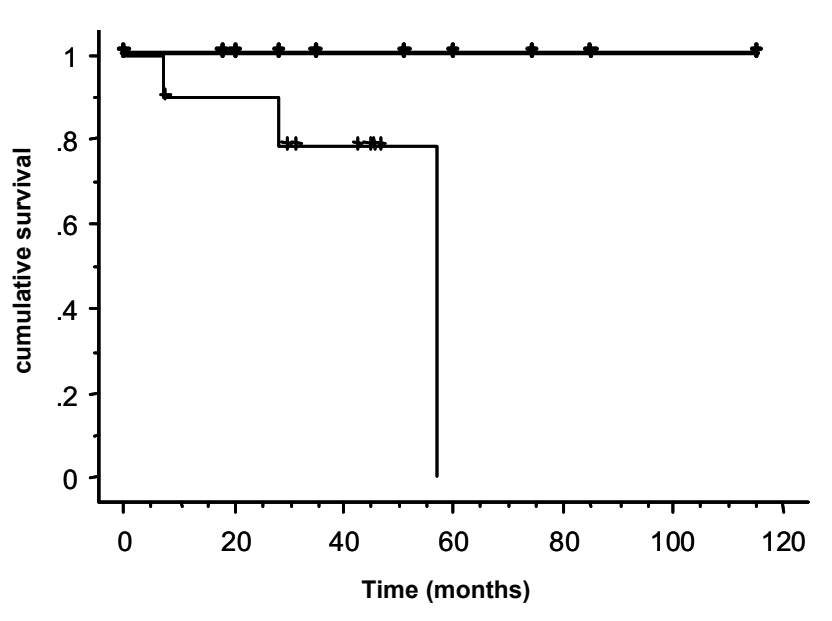

Figure 3

Time-to-local recurrence of HIV-seropositive patients with access to HAART $(n=10)$ (thin line) and T-/N-stage, agematched HIV-seronegative patients $(n=10)$ (thick line) with anal cancer $(p=0.03)$.

HAART died of anal cancer compared to none of the HIVnegative control patients. In the present study, no HIVseropositive patient with HAART died as a result of HIVassociated infections.

\section{Acute toxicity}

Although the frequency of acute grade 3/4 toxicities was doubled in HIV-seropositive individuals compared with matched HIV-seronegative patients (60\% vs. $30 \%$ ), this did not reach statistical significance because of low patient number. Therefore, a worse outcome in respect of acute toxicity can not be excluded. There was no grade 5 toxicity in the HIV-positive group or the matched HIVnegative group.

Cutaneous and gastrointestinal toxicity: Acute skin toxicity grade 3 was seen in 3 HIV-positive patients with HAART resulting in a rate of $30 \%$ compared with $20 \%$ of matched HIV-seronegative patients ( $p=\mathrm{NS})$. In the HIVseropositive patients, no severe diarrhea was observed while it was reported in one HIV-seronegative patient.

Hematological toxicity: Three of six (50 \%) HIV-seropositive patients receiving HAART who were treated with chemotherapy with MMC developed acute thrombocytopenia grade 3 (Table 1), compared to $0 \%$ of 8 matched HIV-negative patients. This resulted in a significant higher severe hematological toxicity rate $(p=0.05)$. Notably, two of the patients had CD4 count above 200 cells/ $\mu \mathrm{l}$.

\section{Late toxicity}

In respect of chronic side effects including chronic skin ulceration grade 3, complaints from chronic proctitis, 
sphincter muscle dysfunction and incontinence grade 1 no significant difference was found between HIV-seropositive and matched HIV-seronegative patients. Prolonged wound healing was seen in only 1 patient with HIV-infection (10\%) without evidence of tumor persistence compared with no patient in the matched HIV-seronegative cohort. Though, this patient developed a secondary lymphoma at the site of ulceration which was treated with chemotherapy. One patient of each group developed sphincter pressure impairment after treatment. The rate of sphincter function preservation was around $70 \%(\mathrm{HIV}+)$ and $100 \%$ (matched HIV-). One HIV-seropositive patient under HAART died 2.5 years after RT because of sigmoid colon perforation, an area outside the RT treatment fields.

\section{Discussion}

HIV-infected individuals are confronted with a an increased risk for cancer disease, including anal carcinoma [1-4]. Although HAART has favorably influenced the incidence of non-Hodgkin lymphoma and Kaposis' sarcoma $[21,22]$, the incidence of anal cancer has remained elevated in HIV-positive individuals [17,23-29]. HAART has a profound influence on a broad variety of organs and physiological systems resulting in improved function of the immune system, especially the CD4 T-cell compartment, and prolongs survival [30-40]. Protease inhibitors and non-nucleoside reverse transcriptase inhibitors are interfering with CT, because they are substrates and potent inhibitors or inducers of the cytochrome P450 (CYP) system [41]. Protease inhibitors may potentially act as radioas well as chemosensitizers $[42,43]$ putatively resulting in either better tumor control or increased toxicity.

This study is the first matched-pair analysis on anal cancer patients with HIV-infection receiving HAART comparing outcome with HIV-seronegative controls accounting for the three most important prognostic-factors T-stage, Nstage and age [44-46]. Several findings are of clinical importance. (i) Standard 3-D conformal RT alone or combined with standard CT can achieve complete tumor response rates of $100 \%$ in patients with HIV-infection under HAART. (ii) Despite the good response rates and maintained treatment with HAART, local failure rate is significantly higher when compared with the prognostically similar tumor-stage and age matched control cohort possibly compromising colostomy-free and cancer-specific survival. (iii) Nevertheless, disease-free and overall survival is similar in HIV-positive patients under HAART compared with HIV-negative patients. (iv) Standard chemo-radiation with mitomycin-C is associated with a high rate of severe acute hematological toxicity but not with increased long-term side effects in HIV-seropositive patients with HAART. (v) HDR-brachytherapy was applied less frequently to HIV-seropositive patients and adherence to chemotherapy was more difficult.
Since the introduction of HAART, one comparative [18] and six non-comparative retrospective reports have evaluated the outcome of HIV-seropositive patients with access to HAART $[1,17,47-50]$. Though, only 4 of these studies included more than 8 patients $[1,17,18,50]$. The study by Kinsella et al., presented at the Annual Meeting of the American Society for Therapeutic Radiology and Oncology (ASTRO) 2005, also compared consecutive HIV-seropositive patients receiving HAART with consecutive HIVseronegative patients and concluded that standard combined chemo-radiation with 5-FU and MMC or cisplatin can achieve good tumor response (86 \%) and DFS (79\%) in HIV-seropositive patients under antiretroviral therapy, similar to the HIV-negative cohort [18]. Tumor response was $100 \%$ in our study and DFS at 5 years $(70 \%)$ compares similar to the results of Kinsella et al.. In contrast to the study by Kinsella et al., we observed an increased local recurrence rate in HIV-seropositive patients resulting in a colostomy rate of $30 \%$. Colostomy rate was not reported by Kinsella et al. The follow-up of our study was considerably longer with 44 months compared with 28 months in their study. It seems that a long follow-up time may be important in HIV-seropositive patients since in our study 1 HIV-seropositive patient had a local failure after 57 months which was not observed in the 81 HIV-seronegative patients. Importantly, HIV-seronegative patients in our study were TNM- as well as age- matched while in the study by Kinsella et al. the HIV-seronegative cohort included more advanced tumor stages (III and IV). Additionally, HIV-seronegative patients were an average of 17 years older than HIV-positive patients which may represent a different prognostic cohort. In respect of toxicity, they observed a low hematological severe toxicity rate in HIV-positive patients which is different to our study. This may be explained in part by the use of cisplatin instead of MMC. If so, cisplatin might be an advantageous alternative to MMC if applied at standard dose and not at highdose like in the study by Blazy et al. [50]. Another study by Allen-Mersh et al. reported treatment and toxicity outcome after chemo-radiation in 46 HIV-seropositive patients with sufficient response to HAART [17]. After a median follow-up of 35 months, 1-year OS ( $85 \%)$ was comparable to our results (90\%). In line with our study and not the study by Kinsella et al., they also noticed a high recurrence rate of $34 \%$ after 1 year. In our analysis, local failure rate was $20 \%$ (1 year) and $30 \%$ (4 years). Due to toxicity, $22 \%$ of the HIV-positive patients required RT breaks or altered chemotherapeutic regimens and $78 \%$ of the patients experienced grade I-III toxicity. $70 \%$ of patients were reported to receive MMC. In our study $60 \%$ experienced acute grade III/IV toxicities and $50 \%$ of the patients receiving MMC had severe thrombocytopenia requiring dose reduction. The importance of the CD4 count to toxicity of chemo-radiation was emphasized by Hoffman et al. who compared patients of the pre-HAART 
era in respect of $\mathrm{CD} 4$ count and found an increased rate of acute side effects associated with low CD4 counts [16]. The CD4 counts in the cohort of Allen-Mersh et al. may have been higher than the CD4 counts of the patients in the present trial. Notably, in the present study, two of the three patients with severe thrombocytopenia had a CD4 count above 200 cells/ $\mu$ l. Due to the small number of patients in the present study, no conclusions regarding CD4 counts are made. It is debatable, whether HAART contributed to the elevated acute toxicity. Some reports suggested a sensitizing effect of protease inhibitors on chemotherapy [42] or radiotherapy [43].

Results from randomized trials compare similar to ours regarding tumor response (100\%), tumor progression at 1 year $(20 \%)$ and OS (70 \% at 5 years). In the study by Bartelink et al. corresponding values were approximately $94 \%, 17 \%$ and $56 \%$ [51]. 4-year OS was $74 \%$ in the trial by Flam et al. [6]. While colostomy-free survival reported was around $70-72 \%$ in the whole patient cohort $[6,51]$, in nodal negative and T1/2 tumors colostomy-free rate was $87 \%$ and above $90 \%$, respectively [6]. Since our study included $80 \% \mathrm{~T} 1 / 2$ and $90 \%$ nodal negative tumors in HIV-seropositive patients, local tumor control rate and colostomy-free survival of below $70 \%$ in HIVseropositive individuals seem to be relatively poor and would be expected higher.

Thus, despite good tumor response and similar OS in our study, our data support the clinical experience that young HIV-seropositive patients with HAART and good performance status are prone to worse treatment outcome, a finding supported by Allen-Mersh et al. or the data of Blazy et al. who showed that high-dose RT ( $60-70 \mathrm{~Gy})$ combined with 5-FU and cisplatin - given at a different regimen, though - resulted in grade 3 neutropenia in 4 of 9 HIVseropositive patients receiving HAART (44\%) [50]. Also, Bower et al. reported on $26 \mathrm{HIV}$-infected patients in the pre- and post-HAART era (16 patients with HAART) that the actuarial 2-year overall survival did not change after introduction of HAART [1].

There must be factors others than age or tumor stage for the higher local recurrence since the patients were well matched in respect of these prognostic factors. Such factors may be either patient-related or treatment-related. Patient-related factors may be persisting immunological alterations even after controlling HIV replication with HAART. Treatment-related factors may be the difficulties to apply full dose chemotherapy [52]. Chemotherapy and MMC in particular, was applied less frequently and with worse adherence in the HIV-seropositive patients either due to non-compliance, co-morbidity or concomitant medication, low CD4 counts, or severe thrombocytopenia before or during treatment. The importance of additional chemotherapy for the local tumor control has been demonstrated in several randomized trials $[6,51,53-55]$. Thus, we assume that chemotherapy is important for the local treatment success in HIV-positive patients, as well.

Another difference of treatment between seropositive and seronegative patients was the use of brachytherapy that was more reluctantly applied in HIV-seropositive patients. The stringent matching procedure for TNM-stage, age and grade to some extent did not allow an additional matching for brachytherapy. Though, retrospective analysis of 81 HIV-seronegative patients at our Department revealed no better outcome for patients receiving a HDR brachytherapy boost compared to patients with an EBRT boost. Due to missing randomized trials or retrospective comparative studies indicative for a definitive clinical benefit of brachytherapy, we lack evidence to encourage the use of interstitial treatment in HIV-seropositive patients with anal cancer [56-59]. In the present cohort, it is not clear whether brachytherapy has been used more reluctantly because of the HIV-infection harbouring a risk of complications and treatment-related death or because of other reasons, such as the particular anatomical presentation of the disease.

There are some limitations to the present study. Because of the low incidence only a small number of patients could be analysed with limited statistical power. Therefore, only clear and important differences were found. Due to the limited number of cases, this study must be considered hypothesis-generating and not conclusive. The case-control analysis improves the validity of the study results although there may still be a selection bias and despite that the controls were derived through a stringent selection algorithm, which did not allow changing matching cases before analysis. Furthermore, when the HIVseropositive patients were compared with all, nonmatched consecutive $81 \mathrm{HIV}$-seronegative patients, timeto-local recurrence was still inferior in HIV-seropositive patients under HAART. Matching for T-/N- stage as well as age is important since both are significant statistical parameters and because the demographics of HIVpatients with anal cancer differ from those of HIV-seronegative patients a fact not considered in the study by Kinsella et al.. Grading is not an independent risk factor when adjusted for stage [60] and gender can not generally be considered as a prognostic factor, although some multivariate analyses suggest that women may have a better prognosis than men [51,61-63]. The performance status was similar in all the patients investigated in this study, never below $80 \%$ of Karnofsky scale [46].

We conclude that HIV-seropositive patients with HAART and a good performance status are likely to achieve a complete response with standard 3-D conformal RT alone or 
combined with standard chemotherapy, although the risk for local relapse is high. Nevertheless, overall survival is comparable to HIV-seronegative patients. Despite good performance status the tolerability of chemo-radiation with mitomycin- $\mathrm{C}$ is limited by the toxicity of full dose chemotherapy. Therefore, in HIV-seropositive anal cancer patients with access to HAART, combined chemo-radiation is challenged to be more efficient at reduced toxicity at which cisplatin may represent a feasible option.

\section{Competing interests}

The author(s) declare that they have no competing interests.

\section{Acknowledgements}

Supported in part by the Cancer League of Zurich, Switzerland. The authors thank Dr. Bernard Davis and Dr. Nicolas Müller for helpful discussions.

\section{References}

I. Bower M, Powles T, Newsom-Davis T, Thirlwell C, Stebbing J, Mandalia S, Nelson M, Gazzard B: HIV-Associated Anal Cancer: Has Highly Active Antiretroviral Therapy Reduced the Incidence or Improved the Outcome? J Acquir Immune Defic Syndr 2004 37(5): $1563-1565$.

2. Chiao EY, Schrag D: Anal cancer incidence in relation to HIV epidemiology. Journal of Clinical Oncology, 2004 ASCO Annual Meeting Proceedings (Post-Meeting Edition). Vol 22, No I4S (July I5 Supplement), 2004: 4080; 2004.

3. Melbye M, Cote TR, Kessler L, Gail M, Biggar RJ: High incidence of anal cancer among AIDS patients. The AIDS/Cancer Working Group. Lancet 1994, 343(8898):636-639.

4. Goedert Jj: The epidemiology of acquired immunodeficiency syndrome malignancies. Semin Oncol 2000, 27(4):390-40I

5. Nilsson PJ, Svensson C, Goldman S, Ljungqvist O, Glimelius B: Epidermoid anal cancer: a review of a population-based series of 308 consecutive patients treated according to prospective protocols. Int J Radiat Oncol Biol Phys 2005, 6 I (I):92-I02.

6. Flam M, John M, Pajak TF, Petrelli N, Myerson R, Doggett S, Quivey J, Rotman M, Kerman H, Coia L, Murray K: Role of mitomycin in combination with fluorouracil and radiotherapy, and of salvage chemoradiation in the definitive nonsurgical treatment of epidermoid carcinoma of the anal canal: results of a phase III randomized intergroup study. J Clin Oncol 1996, I 4(9):2527-2539.

7. Efron JE, Pikarsky AJ, Gervaz P, Locker G, Weiss EG, Wexner SD, Nogueras J]: The efficacy of chemoradiation therapy in HIV seropositive patients with squamous cell carcinoma of the anus. Colorectal Dis 2001, 3(6):402-405.

8. Kim JH, Sarani B, Orkin BA, Young HA, White J, Tannebaum I, Stein $S$, Bennett B: HIV-positive patients with anal carcinoma have poorer treatment tolerance and outcome than HIV-negative patients. Dis Colon Rectum 200I, 44(I 0): I496-I502.

9. Vatra B, Sobhani I, Aparicio T, Girard PM, Puy Montbrun TD, Housset $M$, Baillet F, Hecht F, Chossidow D, Soule JC: [Anal canal squamous-cell carcinomas in HIV positive patients: clinical features, treatments and prognosis]. Gastroenterol Clin Biol 2002, 26(2): $150-156$.

10. Bottomley DM, Aqel N, Selvaratnam G, Phillips RH: Epidermoid anal cancer in HIV infected patients. Clin Oncol ( $R$ Coll Radiol) 1996, 8(5):319-322.

II. Peddada AV, Smith DE, Rao AR, Frost DB, Kagan AR: Chemotherapy and low-dose radiotherapy in the treatment of HIVinfected patients with carcinoma of the anal canal. Int J Radiat Oncol Biol Phys 1997, 37(5): I I0 I- I I05.

12. Chadha M, Rosenblatt EA, Malamud S, Pisch J, Berson A: Squamouscell carcinoma of the anus in HIV-positive patients. Dis Colon Rectum 1994, 37(9):86|-865.
13. Holland JM, Swift PS: Tolerance of patients with human immunodeficiency virus and anal carcinoma to treatment with combined chemotherapy and radiation therapy. Radiology 1994, I 93(I):25I-254.

14. Place RJ, Gregorcyk SG, Huber PJ, Simmang CL: Outcome analysis of HIV-positive patients with anal squamous cell carcinoma. Dis Colon Rectum 200I, 44(4):506-5I 2

I5. Hocht S, Wiegel T, Kroesen AJ, Berdel WE, Runkel N, Hinkelbein W: Low acute toxicity of radiotherapy and radiochemotherapy in patients with cancer of the anal canal and HIV-infection. Acta Oncol 1997, 36(8):799-802.

16. Hoffman R, Welton ML, Klencke B, Weinberg V, Krieg R: The significance of pretreatment CD4 count on the outcome and treatment tolerance of HIV-positive patients with anal cancer. Int J Radiat Oncol Biol Phys 1999, 44(I): I27-I3I.

17. Allen-Mersh T, Hanna-Morris AJ, Goldstone SE, Sparano JA, Elrafei T, Bower M: Is chemoradiation the treatment of choice for anal squamous cell carcinoma developing in HIV-positive patients with access to highly active antiretroviral therapy? 2004:233.

18. Kinsella TJ, Kinsella MT, Reynolds H, Remick S: Comparable Tumor Response and Acute/Late Normal Tissue Toxicities with Standard Combined Modality Treatment for anal Squamous Cell Carcinomas in HIV+ and HIV- Patients. Volume 63. Int J Radiat Oncol Biol Phys; 2005:SI6.

19. AJCC: Cancer Staging Handbook, TNM Classification of Malignant Tumors, 6th edition. 2002:|39-| 44.

20. CTCAE: Common Terminology Criteria for Adverse Events v3.0. http://ctepcancergov 2003

21. Bhaskaran K, Brettle R, Porter K, Walker AS: Systemic non-Hodgkin lymphoma in individuals with known dates of HIV seroconversion: incidence and predictors. Aids 2004, I 8(4):673-68I.

22. Bourboulia D, Aldam D, Lagos D, Allen E, Williams I, Cornforth D Copas A, Boshoff C: Short- and long-term effects of highly active antiretroviral therapy on Kaposi sarcoma-associated herpesvirus immune responses and viraemia. Aids 2004, I 8(3):485-493

23. Palefsky JM, Holly EA, Gonzales J, Berline J, Ahn DK, Greenspan JS: Detection of human papillomavirus DNA in anal intraepithelial neoplasia and anal cancer. Cancer Res 1991, 51(3): $1014-1019$

24. Palefsky JM, Holly EA, Hogeboom CJ, Ralston ML, DaCosta MM, Botts $R$, Berry JM, Jay N, Darragh TM: Virologic, immunologic, and clinical parameters in the incidence and progression of anal squamous intraepithelial lesions in HIV-positive and HIVnegative homosexual men. J Acquir Immune Defic Syndr Hum Retrovirol 1998, I7(4):314-319.

25. Palefsky JM: Human papillomavirus infection and anogenital neoplasia in human immunodeficiency virus-positive men and women. J Natl Cancer Inst Monogr 1998:I5-20.

26. Palefsky JM: Anal squamous intraepithelial lesions: relation to HIV and human papillomavirus infection. J Acquir Immune Defic Syndr 1999, 2 I SuppI I:S42-8.

27. Baillargeon J, Pollock BH, Leach CT, Gao SJ: The association of neoplasms and HIV infection in the correctional setting. Int J STD AIDS 2004, I 5(5):348-35 I

28. Piketty C, Darragh TM, Da Costa M, Bruneval P, Heard I, Kazatchkine MD, Palefsky JM: High prevalence of anal human papillomavirus infection and anal cancer precursors among HIVinfected persons in the absence of anal intercourse. Ann Intern Med 2003, I 38(6):453-459.

29. Heard I, Palefsky JM, Kazatchkine MD: The impact of HIV antiviral therapy on human papillomavirus (HPV) infections and HPV-related diseases. Antivir Ther 2004, 9(I): I3-22.

30. Autran B, Carcelain G, Li TS, Blanc C, Mathez D, Tubiana R, Katlama C, Debre P, Leibowitch J: Positive effects of combined antiretroviral therapy on CD4+ $\mathrm{T}$ cell homeostasis and function in advanced HIV disease. Science 1997, 277(5322): I I 2- I I6.

31. Imami N, Antonopoulos C, Hardy GA, Gazzard B, Gotch FM: Assessment of type I and type 2 cytokines in HIV type Iinfected individuals: impact of highly active antiretroviral therapy. AIDS Res Hum Retroviruses 1999, I 5(I 7): I 499-I508.

32. Plana M, Garcia F, Gallart T, Tortajada C, Soriano A, Palou E, Maleno MJ, Barcelo J], Vidal C, Cruceta A, Miro JM, Gatell JM: Immunological benefits of antiretroviral therapy in very early stages of 
asymptomatic chronic HIV-I infection. Aids 2000, I 4(I3): I92I-1933.

33. Behbahani H, Landay A, Patterson BK, Jones P, Pottage J, Agnoli M, Andersson J, Spetz AL: Normalization of immune activation in lymphoid tissue following highly active antiretroviral therapy. J Acquir Immune Defic Syndr 2000, 25(2): I50-I56.

34. Macias J, Japon MA, Leal M, Saez C, Pineda JA, Segura DI, Ortega J, Lissen $E$ : Structural normalization of the lymphoid tissue in asymptomatic HIV-infected patients after 48 weeks of potent antiretroviral therapy. Aids 200I, I5(I8):237I-2378.

35. Parato KG, Kumar A, Badley AD, Sanchez-Dardon JL, Chambers KA, Young CD, Lim WT, Kravcik S, Cameron DW, Angel JB: Normalization of natural killer cell function and phenotype with effective anti-HIV therapy and the role of IL-10. Aids 2002, I6(9): $125|-| 256$.

36. Hardy GA, Imami N, Sullivan AK, Pires A, Burton CT, Nelson MR, Gazzard BG, Gotch FM: Reconstitution of CD4+ $\mathbf{T}$ cell responses in HIV-I infected individuals initiating highly active antiretroviral therapy (HAART) is associated with renewed interleukin-2 production and responsiveness. Clin Exp Immunol 2003, 134(1):98-106.

37. Ciernik IF, Cone RW, Fehr J, Weber R: Impaired liver function and retroviral activity are risk factors contributing to HIVassociated thrombocytopenia. Swiss HIV Cohort Study. Aids 1999, I3(14): 1913-1920.

38. Aukrust P, Haug CJ, Ueland T, Lien E, Muller F, Espevik T, Bollerslev J, Froland SS: Decreased bone formative and enhanced resorptive markers in human immunodeficiency virus infection: indication of normalization of the bone-remodeling process during highly active antiretroviral therapy. J Clin Endocrinol Metab 1999, 84(I): | 45-I50.

39. Viani RM, Dankner WM, Muelenaer PA, Spector SA: Resolution of HIV-associated nephrotic syndrome with highly active antiretroviral therapy delivered by gastrostomy tube. Pediatrics 1999, 104(6): 1394-1396.

40. Chang L, Ernst T, Leonido-Yee M, Witt M, Speck O, Walot I, Miller EN: Highly active antiretroviral therapy reverses brain metabolite abnormalities in mild HIV dementia. Neurology 1999, 53(4):782-789.

41. Antoniou T, Tseng AL: Interactions Between Antiretrovirals and Antineoplastic Drug Therapy. Clin Pharmacokinet 2005, 44(2): III-I45.

42. Sparano JA, Wiernik PH, Hu X, Sarta C, Henry DH, Ratech $H$ : Saquinavir enhances the mucosal toxicity of infusional cyclophosphamide, doxorubicin, and etoposide in patients with HIV-associated non-Hodgkin's lymphoma. Med Oncol 1998 I 5(I):50-57.

43. Pajonk F, Himmelsbach J, Riess K, Sommer A, McBride WH: The human immunodeficiency virus (HIV)-I protease inhibitor saquinavir inhibits proteasome function and causes apoptosis and radiosensitization in non-HIV-associated human cancer cells. Cancer Res 2002, 62( I 8):5230-5235.

44. Shepherd NA, Scholefield JH, Love SB, England J, Northover JM: Prognostic factors in anal squamous carcinoma: a multivariate analysis of clinical, pathological and flow cytometric parameters in 235 cases. Histopathology 1990, 16(6):545-555.

45. Greenall MJ, Quan SH, Stearns MW, Urmacher C, DeCosse JJ: Epidermoid cancer of the anal margin. Pathologic features, treatment, and clinical results. Am J Surg I985, I 49(I):95-I0I.

46. Stearns MWJ, Urmacher C, Sternberg SS, Woodruff J, Attiyeh F: Cancer of the anal canal. Curr Probl Cancer 1980, 4(1 2): I-44.

47. Cleator S, Fife K, Nelson M, Gazzard B, Phillips R, Bower M: Treatment of HIV-associated invasive anal cancer with combined chemoradiation. Eur / Cancer 2000, 36(6):754-758.

48. Stadler RF, Gregorcyk SG, Euhus DM, Place RJ, Huber PJ, Simmang $C L$ : Outcome of HIV-infected patients with invasive squamous-cell carcinoma of the anal canal in the era of highly active antiretroviral therapy. Dis Colon Rectum 2004, 47(8): 1305-1309.

49. Adler W, Lee FC, Wong G: Capecitabine, mitomycin C \& radiation for HIV patients with anal squamous cell carcinoma. Journal of Clinical Oncology, 2004 ASCO Annual Meeting Proceedings (Post-Meeting Edition). Vol 22, No I4S (July 15 Supplement), 2004: 4239; 2004.

50. Blazy A, Hennequin C, Gornet JM, Furco A, Gerard L, Lemann M, Maylin C: Anal carcinomas in HIV-positive patients: high-dose chemoradiotherapy is feasible in the era of highly active antiretroviral therapy. Dis Colon Rectum 2005, 48(6): I I76-I I8I.

5I. Bartelink H, Roelofsen F, Eschwege F, Rougier P, Bosset JF, Gonzalez DG, Peiffert D, van Glabbeke M, Pierart M: Concomitant radiotherapy and chemotherapy is superior to radiotherapy alone in the treatment of locally advanced anal cancer: results of a phase III randomized trial of the European Organization for Research and Treatment of Cancer Radiotherapy and Gastrointestinal Cooperative Groups. I Clin Oncol 1997, I 5(5):2040-2049.

52. Chauveinc L, Buthaud X, Falcou MC, Mosseri V, De la Rochefordiere A, Pierga JY, Girodet J, Salmon RJ: Anal canal cancer treatment: practical limitations of routine prescription of concurrent chemotherapy and radiotherapy. $\mathrm{Br} J$ Cancer 2003, 89(I I):2057-206I.

53. Epidermoid anal cancer: results from the UKCCCR randomised trial of radiotherapy alone versus radiotherapy, 5fluorouracil, and mitomycin. UKCCCR Anal Cancer Trial Working Party. UK Co-ordinating Committee on Cancer Research. Lancet 1996, 348(9034): 1049-1054.

54. Bosset JF, Roelofsen F, Morgan DA, Budach V, Coucke P, Jager JJ, Van der Steen-Banasik E, Triviere N, Stuben G, Puyraveau M, Mercier M: Shortened irradiation scheme, continuous infusion of 5 . fluorouracil and fractionation of mitomycin C in locally advanced anal carcinomas. Results of a phase II study of the European Organization for Research and Treatment of Cancer. Radiotherapy and Gastrointestinal Cooperative Groups. Eur J Cancer 2003, 39( I):45-5I.

55. Cummings BJ, Keane TJ, O'Sullivan B, Wong CS, Catton CN: Epidermoid anal cancer: treatment by radiation alone or by radiation and 5-fluorouracil with and without mitomycin C. Int J Radiat Oncol Biol Phys I 99 I, 2 I (5): I I I5- I I 25.

56. Papillon J, Montbarbon JF, Gerard JP, Chassard JL, Ardiet JM: Interstitial curietherapy in the conservative treatment of anal and rectal cancers. Int J Radiat Oncol Biol Phys 1989, 17(6): II6I-II69.

57. Dubois JB, Garrigues JM, Pujol H: Cancer of the anal canal: report on the experience of $6 \mathrm{I}$ patients. Int J Radiat Oncol Biol Phys I99 I, 20(3):575-580

58. Ager P, Samala E, Bosworth J, Rubin M, Ghossein NA: The conservative management of anorectal cancer by radiotherapy. Am J Surg 1979, I37(2):228-230.

59. Ng Ying Kin NY, Pigneux J, Auvray H, Brunet R, Thomas L, Denepoux $R$ : Our experience of conservative treatment of anal canal carcinoma combining external irradiation and interstitial implant: 32 cases treated between 1973 and 1982. Int J Radiat Oncol Biol Phys 1988, 14(2):253-259.

60. Boman BM, Moertel CG, O'Connell MJ, Scott M, Weiland LH, Beart RW, Gunderson LL, Spencer RJ: Carcinoma of the anal canal. A clinical and pathologic study of $\mathbf{1 8 8}$ cases. Cancer 1984, 54(I): II I - I25.

6I. Myerson RJ, Karnell LH, Menck HR: The National Cancer Data Base report on carcinoma of the anus. Cancer 1997, 80(4):805-8I5.

62. Goldman S, Auer G, Erhardt K, Seligson U: Prognostic significance of clinical stage, histologic grade, and nuclear DNA content in squamous-cell carcinoma of the anus. Dis Colon Rectum 1987, 30(6):444-448

63. Goldman S, Glimelius B, Glas U, Lundell G, Pahlman L, Stahle E: Management of anal epidermoid carcinoma--an evaluation of treatment results in two population-based series. Int J Colorectal Dis 1989, 4(4):234-243. 